\title{
Percutaneous mitral commissurotomy in pregnant women - long-term observations
}

Zabiegi przezskórnej komisurotomii mitralnej u kobiet w ciąży - obserwacje odległe

\author{
Maciej Dąbrowski', Zbigniew Chmielak ${ }^{1}$, Marek Dąbrowski², Witold Rużyłło ${ }^{1}$ \\ 1Department of Interventional Cardiology and Angiology, Institute of Cardiology, Warsaw, Poland \\ 2Department of Cardiology and Physiotherapy, Warsaw Medical University, Bielanski Hospital, Warsaw, Poland
}

Post Kardiol Interw 2011; 7, 1 (23): 15-19

DOI: 10.5114/pwki.2011.21187

\begin{abstract}
Background: Percutaneous mitral commissurotomy (PMC) can be safely performed during pregnancy. However, there is still little known about follow-up results after PMC in populations of pregnant women taking into consideration childhood development.

Aim: To evaluate long-term clinical follow-up and echocardiographic data on pregnant patients who underwent PMC in our centre and development of their infants.

Material and methods: From January 1989 to December 1998, 15 pregnant women with mitral stenosis and severe congestive heart failure (mean gestational duration, $31.5 \pm 2.7$ week) underwent PMC. The procedure was successful in all patients, resulting in a significant increase $\left(0.85 \pm 0.3 \mathrm{~cm}^{2}\right)$ in mitral valve area from $1.01 \pm 0.24 \mathrm{~cm}^{2}$ to $2.01 \pm 0.33 \mathrm{~cm}^{2}(p<0.001)$ and New York Heart Association (NYHA) improvement to class I or II (13 and 2 patients respectively).

Results: There was no maternal death, no abortion, no intrauterine growth restriction, and no stillbirth. One baby (6.6\%) had cerebral palsy at birth. Long term follow-up of 17 years and 9 months was completed for 12 patients. Two patients (13\%) underwent re-PMC, and one (6.6\%) surgical mitral valve replacement 15,17 and 19 years after the first procedure, respectively. All babies maintained normal growth and development without any clinical abnormalities, thyroid disease or malignancy.

Conclusion: PMC is a safe and effective procedure, with favourable long-term results in the population of pregnant women with rheumatic mitral stenosis and severe congestive heart failure.
\end{abstract}

Key words: mitral stenosis, mitral valvuloplasty, pregnancy, childhood development

\section{Streszczenie}

Wstęp: Zabieg walwuloplastyki zastawki mitralnej (PMC) może zostać bezpiecznie przeprowadzony u kobiet w ciąży. Dotychczas opublikowano niewiele doniesień na temat odległych wyników PMC wykonywanych u kobiet w ciąży oraz wpływu promieniowania rentgenowskiego stosowanego w czasie PMC na płód i rozwój dziecka po urodzeniu.

Cel: Ocena bezpośrednich i odległych wyników komisurotomii mitralnej przeprowadzonej w Instytucie Kardiologii w Warszawie w grupie pacjentek w ciąży oraz ocena wpływu procedury na płód i późniejszy rozwój dziecka.

Materiał i metody: Między styczniem 1989 r. a grudniem 1998 r. PMC wykonano u 15 ciężarnych z objawami ciężkiej niewydolności serca. Zabiegi przeprowadzono średnio w 31,5 $\pm 2,7$ tygodniu ciąży. U wszystkich pacjentek uzyskano wzrost pola powierzchni zastawki z 1,01 $\pm 0,24 \mathrm{~cm}^{2}$ do $2,01 \pm 0,33 \mathrm{~cm}^{2}$ ( $p<0,001$ ) oraz poprawę wydolności fizycznej do I lub II klasy (odpowiednio 13 i 2 pacjentki) wg NYHA. Nie obserwowano powikłań w czasie dalszego przebiegu ciąży.

Wyniki: U jednego noworodka zdiagnozowano porażenie mózgowe. Dane dotyczące obserwacji odległej wynoszącej średnio 17 lat i 9 miesięcy zebrano od 12 pacjentek. U 2 chorych (13\%) wykonano re-PMC, u jednej (6,6\%) operację wymiany zastawki mitralnej, odpowiednio 15, 17 i 19 lat po pierwszym zabiegu. Wszystkie dzieci żyją. Poza chłopcem z porażeniem mózgowym, rozwijają się prawidłowo i są zdrowe fizycznie i psychicznie.

Wnioski: Zabieg walwuloplastyki zastawki mitralnej u kobiet w ciąży z poreumatycznym zwężeniem zastawki mitralnej i ciężką niewydolnością serca jest leczeniem skutecznym i bezpiecznym dla kobiety i dla płodu.

Słowa kluczowe: zwężenie zastawki mitralnej, walwuloplastyka zastawki mitralnej, ciąża, rozwój dziecka

Corresponding author/Adres do korespondencji:

Maciej Dąbrowski MD, Department of Interventional Cardiology and Angiology, Institute of Cardiology, Alpejska 42, 04-628 Warsaw,

tel.: +48 2281540 14, e-mail: macidabro@yahoo.com

Praca zgłoszona 1.10.2010, wersja poprawiona 19.01.2011, przyjęta do druku 20.02.2011. 


\section{Introduction}

Percutaneous mitral commissurotomy (PMC), performed for the first time by Inoue using a catheter equipped with a balloon, is now a routinely used method of treatment in most patients with isolated, post-rheumatic stenosis of the mitral valve [1]. It was demonstrated that PMC is an effective and safe method of therapy in patients with de novo mitral valve stenosis as well as with recurrence of stenosis after previous interventional treatment [2-9].

Pregnant women are a specific group of patients with mitral valve stenosis in whom accelerated aggravation of heart failure symptoms is often observed [10]. Previous studies showed that PMC is a method of choice in the treatment of pregnant women with haemodynamically significant mitral valve stenosis [11-15]. However, until now there are only a few reports on the long-term results of PMC in pregnant women and on the influence of $X$-ray radiation on the fetus and child development after birth [16]. The aim of the study was to assess the shortand long-term results of mitral valve commissurotomy performed in our centre between 1989 and 1998 in pregnant women and to analyse the influence of the procedure on the fetus and subsequent child development.

\section{Material and methods}

Percutaneous mitral commissurotomy was performed in 15 pregnant women with mitral valve stenosis between January 1989 and the end of December 1998 in the Institute of Cardiology in Warsaw. Mean age of the patients was $35 \pm 5.1$ years (27-43). Procedures were performed between the 27th and 36th week of gestational age (mean $31.5 \pm 2.7$ ). An indication for percutaneous treatment was the onset of significant symptoms of heart failure during pregnancy (NYHA class III). All women had normal exercise capacity before pregnancy.

Echocardiographic examination performed before PMC was used to determine the mobility and thickness of the valve leaflets, changes in the subvalvular apparatus and the presence and size of calcifications on the valve and on the subvalvular apparatus.

Mitral valve area was assessed with a Doppler method based on the pressure gradient half-time and with planimetry [17]. A Doppler method was also used to analyse whether stenosis was accompanied by mitral regurgitation.

Large morphological changes of the valve, presence of diffused calcifications and haemodynamically significant mitral regurgitation were all contraindications to PMC. Sinus rhythm on ECG was present in all patients.

Patients were informed in detail about the possibility of complications during PMC and about the negative influence of $X$-ray radiation on the fetus. All patients gave informed consent for the procedure.

\section{Procedure description}

Balloon valvuloplasty procedures in pregnant women were performed in the Institute of Cardiology in Warsaw with the assistance of an obstetrician-gynaecologist. The stomach and pelvis of pregnant women were covered with a lead apron to protect the fetus from $\mathrm{X}$-ray radiation. The time of fluoroscopy was maximally limited. No contrast agent was used to avoid iodine intake by the fetus which could lead to thyroid dysfunction. A Cournand catheter was introduced through the femoral vein under local anaesthesia and blood pressure in the right atrium, in the pulmonary artery and in the pulmonary capillaries was measured. Subsequently the interatrial septum was punctured to introduce an Inoue catheter over a special wire into the left atrium. The mitral valve was dilated gradually using the Inoue technique [1]. After each balloon inflation left ventricular pressure was measured with the Inoue catheter and followed by catheter retraction and left atrial pressure assessment. The end-diastolic mitral gradient was calculated from the height of the left atrial wave and the end-diastolic left ventricular pressure.

The left atrial wave and end-diastolic pressure values were used to check for the appearance of mitral regurgitation. The procedure ended with pressure assessment in the pulmonary artery and in the right atrium. Control echocardiography was performed on the first day after PMC.

\section{Long-term follow-up}

Long-term follow-up data were not collected in 3 patients. The Department of State Registry of the Ministry of the Interior and Administration was contacted, and it was thus confirmed that all of the patients are alive. All 3 missing patients did not reply to letters with questionnaires sent by post or to telegrams. The remaining 12 patients were contacted by telephone in 2010 to assess their physical capacity, obtain information on repeat PMC procedures or surgery on the mitral valve, and assess whether there had been any negative influence of X-ray radiation (such as abnormalities of growth or psychomotor development).

\section{Statistical analysis}

All statistical analyses were performed with SPSS software. Continuous variables were displayed as means \pm standard deviations and categorical variables were presented as percentages. Student's t-test for paired samples was used to analyse the selected clinical, haemodynamic and echocardiographic parameters before and after the procedure. A $p$-value $<0.05$ was considered statistically significant.

\section{Results}

All of the balloon valvuloplasty procedures were successful. A significant increase of the mitral valve area 
and decrease of the mitral gradient and pressure in the left atrium and in the pulmonary artery were observed. Comparison of the main echocardiographic and haemodynamic parameters before and after the procedure is presented in Table 1. A good direct result of the procedure (mitral valve area $\geq 1.5 \mathrm{~cm}^{2}$, mitral regurgitation $\leq 2+$ ) was achieved in $13(86.7 \%)$ patients. In the remaining two patients the valve area after the procedure was $1.4 \mathrm{~cm}^{2}$.

Exercise capacity improved in all patients -13 patients had NYHA class I and NYHA class II was present in 2 patients.

There were no significant complications during or after the PMC. Four patients had been diagnosed with mild mitral regurgitation $(1+/ 4+)$ on echocardiography before the procedure, and the remaining patients were free from regurgitation. After the procedure mild regurgitation appeared in another 2 patients, while one of the patients deteriorated from mild to moderate regurgitation $(2+/ 4+)$. An episode of transient ischaemic attack with left hemiparesis was observed in one patient during the procedure. All neurological symptoms resolved within 20 minutes. Other patients did not have any complications.

Twelve patients remain in long-term follow-up of 12-21 years (mean 17 years and 9 months). Two patients underwent repeated balloon valvuloplasty (after 15 and 17 years from the initial procedure). One patient was subjected to surgical mitral valve replacement 19 years after PMC. The remaining 9 patients have a persistently good result of the procedure. One of them is in NYHA class III, five in NYHA class II and three in NYHA class I.

Data on the pregnancy course and childbirth following the PMC were obtained from 14 (93\%) patients. Twelve of them delivered on time, including 10 spontaneous deliveries and 2 caesarean operations. Two patients delivered prematurely (in the $33^{\text {rd }}$ week of gestational age - a twin pregnancy - and in the $29^{\text {th }}$ week of gestational age). In both cases delivery was performed by caesarean operation. A boy born in the $29^{\text {th }}$ week was diagnosed with cerebral palsy. The newborns scored a mean of $8.2 \pm 2.9$ points on the Apgar scale. The boy with cerebral palsy had 3 points on the Apgar scale, was placed in an incubator and monitored in the intensive care unit. Information on the children's psychomotor development was obtained from 12 patients. All children are alive. One has cerebral palsy. All others have normal physical growth and psychological development.

\section{Discussion}

During pregnancy there is an increase of heart rate and cardiac output as well as increase in blood volume and decrease of vessel resistance [10]. These physiological reactions of the cardiovascular system may lead to haemodynamic decompensation in women with mitral valve stenosis. Mortality among women with haemodynamically significant mitral valve stenosis during pregnancy is $7 \%$ with peripartum mortality of up to $15 \%$. Mortality index correlates with symptoms of heart failure assessed with the NYHA classification ( $0.4 \%$ in class I or II and up to $7 \%$ in class III or IV) [18-20]. Interventional treatment is a first choice therapy in symptomatic pregnant women with mitral valve stenosis not reacting to pharmacotherapy. Open surgical commissurotomy is relatively safe for the patient, but is related to high risk of fetal death of about 6 to $17 \%$ [21, 22]. Closed surgical commissurotomy in general anaesthesia with the use of extracorporeal circulation is related to even higher fetal mortality of up to $33 \%[23,24]$. Percutaneous commissurotomy is the safest and most effective way of treatment both for the pregnant women and for the fetus, but because of the negative influence of $X$-ray radiation it should be performed after the end of organogenesis (after the $12^{\text {th }}$ week of gestational age). Specialist centres report nearly $100 \%$ safety for the pregnant woman and fetus [1015]. For obvious reasons there have not been any randomized trials comparing surgical treatment and balloon valvuloplasty in pregnant women. In 2001 Souze et al. published a study comparing the direct results of PMC and open surgical commissurotomy in pregnant women [14]. The group of patients treated surgically consisted of 24 women who underwent open commissurotomy between 1985 and 1990, while the PMC group included 21 women who underwent balloon valvuloplasty between 1990 and 1995. There was one newborn death in the periprocedural

Table 1. Echocardiographic and haemodynamic results before and after percutaneous mitral commissurotomy (PMC)

Tabela 1. Porównanie parametrów echokardiograficznych i hemodynamicznych przed przezskórną komisurotomia mitralna (PMC) i po niej

\begin{tabular}{lccc} 
& Before PMC & After PMC & $P$ \\
\hline Mitral valve area (planimetry) $\left[\mathrm{cm}^{2}\right]$ & $1.01 \pm 0.24$ & $2.01 \pm 0.33$ & $<0.001$ \\
\hline Mean transmitral gradient $[\mathrm{mmHg}]$ (Doppler) & $16.6 \pm 6.6$ & $3.8 \pm 1.3$ & $<0.001$ \\
\hline Maximal transmitral gradient $[\mathrm{mmHg}$ (Doppler) & $24.5 \pm 7.7$ & $8.4 \pm 2.5$ & $<0.001$ \\
\hline Systolic pulmonary artery pressure $[\mathrm{mmHg}]$ & $57.8 \pm 23.6$ & $36.1 \pm 10.9$ & 0.013 \\
\hline Mean pulmonary artery pressure $[\mathrm{mmHg}]$ & $41.7 \pm 14.5$ & $22.2 \pm 7.4$ & 0.003 \\
\hline Mean left atrial pressure $[\mathrm{mmHg}]$ & $28.6 \pm 10.4$ & $12.6 \pm 2.9$ & $<0.001$ \\
\hline Cardiac output $[\mathrm{l} / \mathrm{min}]$ & $4.8 \pm 1.4$ & $5.3 \pm 1.3$ & 0.136
\end{tabular}


period in the PMC group and six fetal deaths and two newborn deaths in the surgical group.

The results of our study confirm that PMC is a safe and effective method of treatment in patients with postrheumatic mitral valve stenosis. A successful procedure was performed in all patients with a good direct result achieved in $86.5 \%$ of them. Physical capacity improved to NYHA class I or II in all patients and therefore 12 women were able to deliver on time. It should be noted that there were no significant complications in the periprocedural period.

The major risk for the fetus during valvuloplasty is related to the negative influence of $X$-ray radiation. Current data report that with adequate preparation the radiation dose absorbed by the fetus during balloon valvuloplasty is very small and does not exceed $0.5 \mathrm{mSv}[14,24]$. However, even a small radiation dose may be harmful and therefore there should be adequate protection of the abdomen during the procedure by using a lead apron and maximal reduction of fluoroscopy. It is equally important to avoid contrast injection to protect the fetus from thyroid dysfunction.

One child in our group was born with cerebral palsy. It seems that there was no relation between the procedure and cerebral palsy, because valvuloplasty was performed in the 27th week of gestational age when the potential influence of $X$-ray radiation on fetal development is small. The procedure did not require large radiation doses and there were no haemodynamic complications. The other 13 children were born in good general condition.

Long-term results of PMC in pregnant women are interesting. All patients are alive after over 17 years since the procedure. Three women required another intervention because of recurrence of stenosis, while the remaining patients are treated conservatively. The good long-term results are due to the very good direct results of the procedure which can be achieved in patients with relatively small morphological changes of the valve and the subvalvular apparatus.

In conclusion, percutaneous valvuloplasty of the mitral valve is an effective and safe method of treatment for both the pregnant woman and the fetus. A successful procedure improves the patient's condition and enables a normal pregnancy course, delivery and puerperium. Physical and psychological development in children of women treated with PMC during pregnancy is normal. PMC should be considered as a method of choice in pregnant women with symptomatic mitral valve stenosis.

\section{References}

1. Inoue K, Owaki T, Nakamura T, et al. Clinical application of transvenous mitral commissurotomy by a new balloon catheter. J Thorac Cardiovasc Surg 1984; 87: 394-402.

2. Hernandez R, Banuelos C, Alfonso F, et al. Long-term clinical and echocardiographic follow-up after percutaneous mitral valvuloplasty with the Inoue balloon. Circulation 1999; 99: 1580.
3. lung B, Garbarz E, Michaud P, et al. Late results of percutaneous mitral commissurotomy in a series of 1024 patients. Analysis of late clinical deterioration: frequency, anatomic findings, and predictive factors. Circulation 1999; 99: 3272.

4. Palacios IF, Sanchez PL, Harrell LC, et al. Which patients benefit from percutaneous mitral balloon valvuloplasty? Prevalvuloplasty and postvalvuloplasty variables that predict long-term outcome. Circulation 2002; 105: 1465.

5. Lau KW, Ding ZP, Gao W, et al. Percutaneous balloon mitral valvuloplasty in patients with mitral restenosis after previous surgical commissurotomy. Eur Heart J 1996; 17: 1367.

6. Pathan AZ, Mahdi NA, Leon MN, et al. Is redo percutaneous mitral balloon valvuloplasty (PMV) indicated in patients with post-PMV mitral restenosis? J Am Coll Cardiol 1999; 34: 49.

7. Fawzy ME, Hassan W, Shoukri M, et al. Immediate and long-term results of mitral balloon valvotomy for restenosis following previous surgical or balloon mitral commissurotomy. Am J Cardiol 2005; 96: 971.

8. Z Chmielak Z, Klopotowski M Kruk M, et al. Repeat percutaneous mitral balloon valvuloplasty for patients with mitral valve restenosis. Catheter Cardiovasc Interv 2010; 76: 986-992.

9. Chmielak Z, Karcz M, Konka M, et al. Dwadzieścia lat doświadczeń w wykonywaniu przezskórnej komisurotomii mitralnej. Post Kardiol Interw 2008; 4: 89-96.

10. Desai DK, Adanlawo M, Niadoo DP, et al. Mitral stenosis in pregnancy: a four-year experience at King Edward VIII Hospital, Durban, South Africa. Br J Obstet Gynaecol 2000; 107: 953-958.

11. Rużyłło W, Dąbrowski M, Woroszylska M, Rydlewska-Sadowska W. Percutaneous mitral commissurotomy with the Inoue balloon for severe mitral stenosis during pregnancy. J Hart Valve Dis 1992; 1: 209-212.

12. Patel JJ, Mitha AS, Hassen F, et al. Percutaneous balloon mitral valvotomy in pregnant patients with tight pliable mitral stenosis. Am Heart J 1993; 125: 1106.

13. Iung B, Cormier B, Elias J, i wsp. Usefulness of percutaneous balloon commissurotomy for mitral stenosis during pregnancy. Am J Cardiol 1994; 73: 398.

14. de Souza JA, Martinez EE Jr, Ambrose JA, et al. Percutaneous balloon mitral valvuloplasty in comparison with open mitral valve commissurotomy for mitral stenosis during pregnancy. J Am Coll Cardiol 2001; 37: 900.

15. Sivadasanpillai H, Srinivasan A, Sivasubramoniam S, et al. Longterm outcome of patients undergoing balloon mitral valvotomy in pregnancy. Am J Cardiol 2005; 95: 1504.

16. Esteves CA, Munoz JS, Braga S. Immediate and long-term followup of percutaneous balloon mitral valvuloplasty in pregnant patients with rheumatic mitral stenosis. Am J Cardiol 2006; 98: 812-816.

17. Hatle L, Angelsen BA, Tromsdal A. Noninvasive assessment of atrioventricular pressure half-time by Doppler ultrasound. Circulation 1979; 60: 1096-1104.

18. Glantz JC, Pomerantz RM, Cunningham MJ, Woods JR Jr. Percutaneous balloon valvuloplasty for severe mitral stenosis during pregnancy: a review of therapeutic options. Obstet Gynecol Surv 1993; 48: 503-508.

19. Nercolini DC. Percutaneous mitral balloon valvuloplasty in pregnant women with mitral stenosis. Cathet Cardiovasc Intervent 2002; 57: 318-322.

20. Notrica M, Wisner J, Villagra L, et al. Live-saving percutaneous mitral valvuloplasty on a pregnant woman with refractory cardiogenic shock. Heart Lung Circ 2009; 18: 301-304. 
21. Knapp RC, Arditi LI. Closed mitral valvulotomy in pregnancy. Clin Obstet Gynecol 1968; 11: 978-991.

22. Schenker JG, Polishuk WZ. Mitral valvotomy during pregnancy. Surg Gynecol Obstet 1968; 127: 593-597.

23. Vosloo S, Reichart B. The feasibility of closed mitral valvotomy in pregnancy. J Thorac Cardiovasc Surg 1987; 93: 675-679.

24. Esteves CA, Ramos AIO, Braga SLN. Effectiveness of percutaneous balloon mitral valvotomy during pregnancy. Am J Cardiol 1991; 68: 930-934. 